\title{
The Rare Sides of Twin Research: Important to Remember/Twin Research Reviews: Representation of Self-Image; Twins With Kleine- Levin Syndrome; Heteropaternal Lemur Twins; Risk of Dental Caries/ In the Media: High-Society Models; 'Winkelevii' Super Bowl Twins; Multiple Birth $\times$ Three; Twin Sister Surrogate; A Presidential Twin?
}

\author{
Nancy L. Segal \\ Department of Psychology, California State University, Fullerton, CA, USA
}

\begin{abstract}
This article explores some rare sides of twin research. The focus of this article is the sad plight of the Dionne quintuplets, born in Canada in 1934. However, several other studies belong in this category, such as Dr Josef Mengele's horrifying twin research conducted at the Auschwitz concentration camp, Dr John Money's misguided attempt to turn an accidentally castrated male twin into a female, Russian scientists' cruel medical study of conjoined female twins and Dr Peter Neubauer's secret project that tracked the development of separated twins. Reviews of current twin research span twins' representation of self-image, twins with Kleine-Levin Syndrome, heteropaternal twinning in lemurs and factors affecting risk of dental caries. Media coverage includes a pair of high-society models, a book about the 'Winkelevii' twins, Super Bowl twin teammates, a family with three sets of fraternal twins, a twin sister surrogate and a near presidential twin.
\end{abstract}

Keywords: Dionne quintuplets; Josef Mengele; accidental castration; conjoined twins

\section{Some Rare Sides of Twin Research: Important to Remember}

Twin research is a vibrant and informative undertaking that has yielded a wealth of vital information regarding factors affecting behavioral traits (e.g., intelligence, personality and interests), physical measures (e.g., height, weight and skin tone) and medical conditions (e.g., schizophrenia, diabetes and cancer; Segal, 2017). In recent years, twin methods have been increasingly applied by investigators representing fields as diverse as neuropsychology (Koenis et al., 2018), economics (Lång \& Nystedt, 2018) and space science (Garrett-Bakelman et al., 2019). Given the foregoing, it is easy to forget that a few rare twin studies had very disturbing sides, causing physical harm and/or psychological damage to twins and their families. Some twins studied at Auschwitz-Birkenau during the Holocaust were even put to death. It is important to recall these studies in order to prevent them from recurring. It is possible that some professionals and members of the concerned public are familiar with these activities, but are less cognizant of their severity and scope. It is also possible that some individuals are unaware that these studies have been conducted.

The impetus for preparing this article comes from a book I am currently researching and writing, which takes a detailed look at

Author for correspondence: Nancy L. Segal, Email: nsegal@fullerton.edu

Cite this article: Segal NL. (2019) The Rare Sides of Twin Research: Important to Remember/Twin Research Reviews: Representation of Self-Image; Twins With KleineLevin Syndrome; Heteropaternal Lemur Twins; Risk of Dental Caries/In the Media: High-Society Models; 'Winkelevii' Super Bowl Twins; Multiple Birth $\times$ Three; Twin Sister Surrogate; A Presidential Twin? Twin Research and Human Genetics 22: 419-424, https://doi.org/10.1017/thg.2019.84 the twin study behind two recent documentary films. The films are The Twinning Reaction (2017), directed by Lori Shinseki, and Three Identical Strangers (2018), directed by Tim Wardle. Both films explored a prospective study of separated infant twins in the New York City area that originated in the early 1960s. The twins were adopted by different families and their behavioral, physical and medical characteristics were tracked without the knowledge of their parents. Most significantly, these mothers and fathers did not even know that they were raising one member of a twin set; they were only told that researchers would be visiting their home periodically because their child was already enrolled in a developmental study. This study has been controversial with people who are strongly defending the work and others who are completely opposed. In the course of conducting research for the book I am writing, I recalled several prior investigations involving twins and other multiples that are highly disturbing and disreputable. I will focus on the Dionne quintuplets, but will reference a number of these other studies.

\section{Dionne Quintuplets}

The identical Dionne quintuplets were born on May 28, 1934, in a rural town in Ontario, Canada (Berton, 1977). Their parents, Oliva and Elzire, were a poor farming couple who were already raising a family of five; as such, the arrival of the quintuplets nearly doubled their family size. The babies were not expected to live, due to their early delivery and very low birth weight, but all five of them did. They remain famous for being the first set of quintuplets in which all members survived, and the 34th set on record since 1694 
(Foster \& Carson, 1923; Hamblen et al., 1937). Coming as they did during financially depressed times, they brought hope and joy to the people of their town and to those who lived elsewhere.

One source listed the order of the quintuplets' birth as Yvonne, Annette, Cécile, Émile and Marie, but that is uncertain (Wikipedia, 2019). In his first publication on the topic, written when the babies were 2 months old, the delivering physician, Dr Allan R. Dafoe, noted that the babies' birth order was unknown (Dafoe, 1934). He could only say that the three larger newborns (Annette, Cecile and Yvonne) arrived ahead of the two smaller ones (Marie and Émilie) during their vaginal delivery at home. Dafoe also noted that a single placenta ('definitely single') with five cords was expelled, but given the chaotic circumstances, the placenta was removed and destroyed. Interestingly, Marie and Émilie showed 'cross-resemblance' in their palms and evidence of reversals in their hair whorl and handedness; about $25 \%$ of monozygotic (MZ) twins show such mirror-imaging effects (Segal, 2017).

Dafoe was incorrect that the Dionnes were the 33rd quintuplet set on records set. As I indicated, they were the 34th such set.

The Dionne quintuplets were truly a phenomenon because multiple births beyond twins were exceedingly rare in the early1920s and 1930s. In vitro fertilization (IVF), which has dramatically raised the rate of twinning and higher multiple births, was developed in Great Britain in 1978 and was not available in the USA and Canada until 1981 and 1983, respectively (CBC Digital Archives, 1984; Comeau, 2013). As I indicated above, the rarity of a quintuplet set was exciting and helped lift the bleak mood of the nation. However, a team of misguided physicians and a group of self-centered government officials took advantage of this event. They exploited the quintuplets and their overwhelmed parents, bringing sad damage to the quint's lives. The five little girls became the objects of study and entertainment, and were turned into an industry that satisfied the financial greed of many.

At the age of 4 months, the five sisters were removed from their family's home and brought to live in a hospital that was specially built for them by Dr Dafoe. They became Wards of the King with the passage of the 1935 Dionne Quintuplets Guardianship Act, a status that remained in place until they turned 9. They lived at the hospital fully isolated from others with the exception of the millions of tourists who bought tickets in order to catch a glimpse of them. Their new home was called 'Quintland'. In addition, visitors were able to purchase dolls, books, fans and posters of the quintuplets. Some of these memorabilia were bequeathed to me from identical twin Kay Cassill, who founded and directed the Twins Foundation in Providence, Rhode Island for many years (Cassill, 1984). When she retired I was the fortunate recipient of a great deal of her material. Cassill (1982) is also the author of the book Twins: Nature's Amazing Mystery.

Dr William E. Blatz, then Director of the University of Toronto's Institute of Child Study, and his colleagues observed and recorded virtually all aspects of the quints' behavioral and physical development. This was not difficult to do because the five were 'captive' in Quintland. The findings are presented in a comprehensive volume, organized into six chapters describing their biology, mental growth, early social development, development of self-discipline, routine training and early spoken language (Blatz et al., 1937). Numerous charts, graphs and pictures are also included. These data were obtained at the high cost of the girls' emotional wellbeing.

The quints' parents won back custody of their children when they turned 9 and the five girls returned home, but it was not a happy reunion. In a chilling account of their experience written years later, they describe harsh treatment by their mother and abuse by their father. Some of the money put into their trust had also disappeared, although they eventually received some compensation from the Canadian government. And in public statements made as adults, they have warned against the shocking mistreatment of multiple birth babies for financial gain and lively entertainment.

In an open letter to the parents of the McCoughey septuplets, born in 1997 in Des Moines, Iowa, three of the surviving quintuplets, Annette, Cécile and Yvonne wrote:

Our lives have been ruined by the exploitation we suffered at the hands of the government of Ontario, our place of birth. We were displayed as a curiosity three times a day for millions of tourists ... We sincerely hope a lesson will be learned from examining how our lives were forever altered by our childhood experience. If this letter changes the course of events for these newborns, then perhaps our lives will have served a higher purpose. (Dionne et al., 2001).

Their pain endures. In a 2017 interview with a New York Times reporter, the remaining two quintuplets, Annette and Cécile, recalled the constant stares from onlookers while they were trying to play - a 'sort of theft' of their childhood. They felt like the 'servants and slaves [of the investigators]. It was not human' (Austen, 2017).

A museum housed in the original Dionne home is a project that has not moved forward, given the costs that their birth city of North Bay does not want to accept. However, they are pleased that the new Dionne Quints Heritage Board is working to preserve their home and to organize commemorative events (Dionne Quints Heritage Board, 2019). Visitors to their website (https:// dionnequintshome.com/) can view the boards' future plans, survey photographs, examine artifacts and watch videotapes of the quints' early and later behaviors and activities. This museum will, hopefully, prevent the further exploitation of young multiple birth children, as well as anyone whose birth circumstances present unusual professional opportunities to researchers. Annette and Cécile are divided over whether or not their museum will serve as a warning sign that children need protection (Austen, 2017). They can only hope that it will. Unfortunately, as I indicated, there are other examples in which twins were badly abused at the hands of physicians and scientists.

\section{Josef Mengele}

The research activities conducted during the Holocaust remain unimaginable. Between the spring of 1943 and the winter of 1945, an estimated 1500 twin pairs passed through the Auschwitz-Birkenau concentration camp in Poland. These twins, as well as individuals with genetic anomalies, were subjected to horrific medical procedures in the name of research. The work was conducted by the infamous physician, Dr Josef Mengele. The year 1985 marked the 40th anniversary reunion of the camp's liberation, bringing a number of the twins, family members and government officials to the camp. This gathering was followed by a 3 day's public hearing on Mengele's war crimes, held at Yad Vashem (Hand and Name), Israel's Holocaust Memorial and Research Institute, in Jerusalem. I attended both of these events (Segal, 1985).

Six months later, in June 1985, it was revealed that Mengele had been living under a false name in southern Brazil, and had died from a drowning accident. The twins I have interviewed were divided as to the potential use of the data collected on them some believed it should be used to justify their suffering, whereas 
others feel that any use of this material would communicate the wrong signal to investigators and to the public (Segal, 1992).

\section{Accidental Castration}

Another example of the horrific misuse of twins is a case study involving an attempt to change an accidentally castrated identical male twin into a female. This effort was a failed experiment disguised as a success. The story of the twin, his twin brother and his family is well documented in the book As Nature Made Him, by journalist John Colapinto (2000).

It began with the 1965 birth of identical twin boys, Bruce and Brian, to Janet and Ron Reimer of Winnepeg, Canada. When the babies were 7 months old they experienced difficulty urinating, a problem that was to be corrected by circumcision at a nearby hospital. The procedure was performed using a cautery machine, rather than the usual scalpel. The current was set on the lowest level, but when it twice failed to work it was adjusted upward, destroying Bruce's genitalia. There were few corrective options available in those days and the Reimers were devastated. However, 10 months later they happened to listen to a television program featuring Dr John Money, of Johns Hopkins University, who was discussing sex change operations he had been performing. Janet contacted Dr Money and his enthusiasm for changing Bruce into a girl was immediate. In fact, it was an ideal case of co-twin control because Bruce had an unaffected identical twin brother.

Janet, who changed her son's name to Brenda, was advised to put him in dresses, let his hair grow long and only allow access to female-typical activities. Surgeries and hormonal treatments would take place later. However, over the years it was clear that this attempt to change Bruce's sex was unsuccessful - he was interested in male-typical activities, was socially isolated and was failing in school. Nevertheless, Money wrote about the case anecdotally, framing it as a success. The truth was exposed in 1997 when Dr Milton Diamond of the University of Hawaii (who had always questioned the success of the experiment and had tried to find out more about it) identified Canadian psychiatrist, Dr H. Keith Sigmundson, who had been involved in Brenda's care. Sigmundson knew that the case was a failure, but admitted that he had lacked the confidence to challenge such a highly esteemed figure as John Money. Diamond and Sigmundson co-wrote a paper reporting the truthful outcome (Diamond \& Sigmundson, 1997).

Brenda was told the truth at the age of 14 years and immediately transitioned back into being a male named David. It turned out that Bruce was the first normally born male to be subjected to such a sex change procedure; Dr. Money's previous cases had involved hermaphrodites. Sadly, both twins ended their lives, Brian in 2002 and David in 2004 (Colapinto, 2004).

\section{Conjoined Twins}

Finally, a recent book by Juliet Butler (2018) is a fictionalized account of the true exploitation of conjoined Russian twins, Masha and Dasha Krivoshlyapova, born in 1950 (Latimer, 2017). The twins shared their blood system, but had separate nervous systems. Physicians were curious to learn about their ability to adjust to different conditions, such as hunger, sleep deprivation and temperature change. Their mother was told that she had delivered a mutant child, and that it was being taken from her. However, during the night a nurse secretly brought the twins to her and she loved them instantly. She refused to sign away her parental rights.
However, doctors then falsely informed her that they had died in order to take them away for study.

Each twin was injected with various substances, such as radioactive iodine, to see how the other twin would react. The procedures were unnecessary and extremely painful. Eventually, the twins were moved to state-run institutions. They passed away at 53 years of age, first Masha and then Dasha $17 \mathrm{~h}$ later. This case is relevant in light of a pair of conjoined Canadian twins, Tatiana and Krista Hogan.

Tatiana and Krista are 10-year-old craniopagus twins, meaning that they are joined at the head (CBCDocsPov, 2019). These twins are especially interesting to scientists because their brains are connected by a 'thalmic bridge', that is, tissue linking one thalmus to the other. The thalmus transmits motor and sensory signals and is also the seat of consciousness. The girls claim that they know each other's thoughts. In addition, they share taste and touch, but their limb control differs - one twin controls three arms and a leg, while the reverse is true for the other twin. They are fortunate to have a loving family that does not allow them to be abused in any way.

This article was not easy to write. I also suspect that the material is not easy to read, given that most twin researchers care deeply about their participants who give so generously of their time. The book I am writing about the 1960s-1970s New York Child Development Center twin study will be similarly challenging but that story and the others I have cited need to be told.

\section{Twin Research Reviews}

\section{Representation of Self-Image}

$\mathrm{MZ}$ and dizygotic (DZ) twins' perceptions of themselves in relation to their twins are fascinating to consider. A study by Prino et al. (2019) included not only twins but also singletons with siblings as an additional informative comparison group. The sample of 105 individual children included $20 \mathrm{MZ}$ males, $14 \mathrm{MZ}$ females, 19 DZ males, 17 DZ females, 17 non-twin males and 18 non-twin females. Slightly over half the DZ twins were from same-sex pairs. The children were drawn from a preschool in northern Italy and ranged in age from 4 years to 6 years, 6 months, with a mean age of 5 years, 5 months. Each child was asked to draw a picture of the self, then a picture showing them together with their co-twin or sibling. Several sample drawings have been reproduced in the article and are quite interesting to examine.

The key findings were that (1) MZ twins tried to distinguish themselves from their co-twin to a greater degree than DZ twins and non-twins; (2) in some cases, MZ twins distinguished themselves by distortion, in that they drew figures showing opposite features or qualitative differences in hair color or eye color; (3) DZ twins produced drawings that showed greater similarity between the self and co-twin, even among the opposite-sex pairs; and (4) non-twins also tended to depict the actual physical features of themselves and their siblings. The investigators suggested that the twins' findings, while unexpected, may reflect the different complex processes that characterize the development of identity in $\mathrm{MZ}$ and $\mathrm{DZ}$ twin pairs. They also suggest that parental attitudes and treatment of twins may be important, for example, they propose that the parents of $\mathrm{DZ}$ twins may try to minimize differences between their two children, thereby enhancing the children's own perceptions of their within-pair similarity. These ideas are speculative and in need of further study. It seems unlikely that parental treatment overrides twins' own perceptions of their twinship, but perhaps that is true in very young children. 
It is important to note that Prino et al. (2019) did not provide the methods by which they determined the zygosity of the twins. If $\mathrm{MZ}$ twins were assigned as DZ, this inaccurate assignment might explain the results to some extent, especially given the small size of the sample.

\section{Twins With Kleine-Levin Syndrome}

Kleine-Levin Syndrome (KLS) is a genetically based condition involving recurrent hypersomnia (excessive sleeping that can last for days), as well as a range of other symptom including (but not limited to) compulsive eating, confusion and impaired speech. KLS has been associated with the gene $D Q B 1^{*} 02: 01$. A friend of mine has a son affected with this condition, providing the impetus for conducting a literature search for studies involving twins. Despite some reports of familial KLS, albeit infrequent (9/239 cases), only a single case study of an MZ male twin pair from Spain was available, identified as the first by its authors (Peraita-Adrados et al., 2012).

The twins in question were male and MZ, as diagnosed by HLA and several polymorphic markers on chromosomes 11 and 15. They were referred for clinical treatment, then agreed to participate in a case study at the age of 33 years. Despite their concordance for the disorder, they showed different symptoms and different degrees of severity. Twin 1 experienced his first episode at the age of 16 years when he suffered from rhinitis (inflammation and swelling of the mucus membrane of the nose; see Fried, 2019) and his last at the age of 29 years. The mean duration of his episodes was 15 days, but they shortened over time. Among his symptoms were hypersomnia, feelings of unreality, depression and partial amnesia. He also showed decreased eating, which is less typical of KLS patients. In between episodes, his behaviors were normal.

Twin 2 experienced his first episode of KLS at the age of 17 years, following the end of his first romantic relationship, and the last episode at the age of 31 years. His symptoms were more typical of those associated with KLA, such as hypersomnia, compulsive eating and transient amnesia. Interestingly, the relevant gene identified in the twins, $D Q B 1^{*} 06: 01$, differed from the one that has been previously linked to KLS; see above. The researchers suggested that their observation raises the possibility of 'genuine genetic forms' of this condition (Peraita-Adrados et al., 2012, p. 595).

\section{Heteropaternal Lemur Twins}

Heteropaternal twins (twins conceived by different fathers) are of great interest to human researchers. These cases are important because their overrepresentation in a small twin sample could yield misleading estimates of heritability. Furthermore, knowledge of zygosity has significant implications for individual identity and medical history (Craig et al., 2015). Only 10 such cases have been documented in the scientific literature, the last one in 2019 (Segal et al., 2019), although underreporting of these twins is likely. It is, therefore, instructive to examine their frequency in other species.

Heteropaternity in ring-tailed lemurs (Lemur catta) was studied by two California investigators (Parga \& Nansen, 2019). The data were gathered on 14 twin sets born in a colony of St Catherine's Island in the state of Georgia, located in the southern part of the USA. The twins were delivered between 2010 and 2013. Ten polymorphic microsatellite markers were used to assess the paternity of the co-twins, collected during the first mating cycle of four mating seasons. All twin pairs were dizygotic, as evidenced by different multilocus within-pair genotypes. Heteropaternity was evident in three cases or $21 \%$ of the sample, as determined by a microsatellite panel of 10 loci that has 0.998 exclusionary power for determining sires. All sires of the three pairs in question were members of their resident group, with one exception.

It was suggested that multiple mating among female lemurs may be an adaptive strategy for enhancing genetic diversity among offspring, such that selection for this behavior would be positive. It may be that this same interpretation applies to human and other nonhuman populations. There is some evidence that DZ twins are overrepresented among illegitimate births, and are linked to coital frequency. It has been suggested that these findings may reflect a tendency by some individuals to attract multiple sexual partners (Campbell, 2005; James, 1992).

\section{Risk of Dental Caries}

Studies of twins reared apart and together have yielded considerable evidence of genetic influence on dental and periodontal variables, including cavities (caries), teeth present, restored surfaces and attachment loss (Vieira et al., 2014; also see Segal (2012)). Therefore, it was surprising to review a twin study reporting the opposite result. Australian researchers Silva et al. (2019) examined dental caries risk in a sample of 172 twin pairs (71 MZ and $101 \mathrm{DZ}$ ) who ranged in age from 6 to 9 years, with the majority being aged 7 years or younger. Zygosity was assessed by DNA analyses from umbilical cord and/or buccal samples. Dental examinations were conducted either at a research facility or at the twins' homes by two trained oral health professionals. It is likely that each twin was assessed by a different examiner to minimize measurement bias, although that is not made explicit.

Unadjusted concordance estimates of caries risk were 0.74 for $\mathrm{MZ}$ twins and 0.69 for DZ twins, a difference that does not support genetic effects. After adjusting for relevant confounding variables, factors such as water fluoridation and maternal obesity were linked to caries risk. Given the young age of the twins, it is perhaps not surprising that a genetic effect was not found - twin studies of behaviors such as religiosity and sports participation also failed to find genetic influence on their respective measures when twins were young and living at home, subject to common parental rearing practices. However, when twins approached adolescence and adulthood, offering greater freedom of personal choice, genetic effects were observed (Koenig et al., 2005; Stubbe et al., 2005).

\section{In the Media}

\section{High-Society Models}

On May 2, 2019, Vogue Magazine fashion editor and former model, Gloria Schiff, passed away at the age of 90 years (Seelye, 2019). The modeling careers of Schiff and her twin sister, Consuelo Crespi, were launched when they were noticed by a fashion photographer at the age of 15 years. They were also the first twins to model for the Toni Home Permanent, explaining the origin of the famous phrase, 'Which twin has the Toni?' They appear to be an identical pair, based on photographs and the fact that one twin once substituted for the other during an interview.

Both twins were married and led 'glittery social lives' (p. B12), but preferred the company of one another. They spoke on the telephone with each other every night, regardless of where in the world they might be. Consuelo passed away at the age of 82 years from a stroke, after which Gloria told Vanity Fair Magazine that she was angry, that they were always close and that their eight-two year's relationship lasted longer than most marriages. 


\section{Winkelevii}

The identical Winkelvoss twins, Cameron and Tyler, are famous on a number of levels. They competed as rowers in the 2008 Olympics held in Beijing, placing sixth (McCarthy, 2008). They also settled a lawsuit with Facebook head Mark Zuckerberg over their claim that he stole their idea for his social media platform. The twins are now the focus of a 2019 book, Bitcoin Billionaires: A True Story of Genius, Betrayal, and Redemption, by Ben Mezrich. Mezrich (2019) tells the story of the twins' role in resurrecting Bitcoin as a viable currency and its subsequent fall. I have not read the book, which received a mixed review in the New York Times, but it promises to engage anyone interested in the collaborative occupational choices made by identical twins (Enrich, 2019).

\section{Super Bowl Twins}

An article published shortly before the 2019 Super Bowl announced that Devin and Jason McCourty would be the first twins to become teammates in the 2019 Super Bowl (Hightower, 2019). The twins, who appear to be identical based on inspection of photographs, played football together since the age of 12 years when they were members of the Valley Cottage Pop Warner League in Nyack, New York. Their personal records show that they finished the season with the same number of touchdowns.

However, the twins' professional athletic careers began apart. Jason played for the Tennessee Titans for 8 years, followed by a single season with the Cleveland Browns. During those 9 years, he never experienced a playoff game. Then he was traded to the New England Patriots where he was reunited with his twin brother Devin, who had enjoyed two Super Bowl wins with that team. Jason regarded the upcoming Super Bowl as a truly rare moment, an opportunity to recapture the days when he played football with his twin.

It turned out that the Patriots defeated the Los Angeles Rams 13-3 (Crist, 2019). It also happens that the McCourty brothers are the first twins to play on the same team since 1926, when Gene and Tom Golsen played together for the Louisville Colonels (Bell, 2019).

\section{Multiple Birth $\times$ Three}

In April 2019, Pam and Taylor Armstrong made news in their home province of Alberta, Canada and around the world with the natural birth of their third fraternal twin pair (Graveland, 2019). Pam had previously delivered twins Brynlee and Parker (male-female, aged 9 years), and Emery and Adileigh (femalefemale, aged 5 years) before going on to have Maverick and Blakely (male-female, newborns). Interestingly, twins occurred only once before in Pam's family, when her grandmother delivered a set. Pam is now 34 years old, just below the age at which older women's tendency to conceive twins starts to rise (Segal, 2017). While it is known that fraternal twinning has a genetic component, the mode of transmission is uncertain. Fraternal twinning is also affected by other factors, among them ethnicity, maternal height and maternal weight. The bases of the Armstrong's three twin pairs have yet to be determined.

\section{Twin Sister Surrogate}

Fraternal twins, Whitney Bliesner and Jill Noe, made news when Jill delivered her sister's male-female twins, Rhett and Rhenley, on June 7, 2019 (Juneau, 2019; Pelletiere, 2019). This pregnancy was unusual because Whitney was unable to conceive and carry a child safely, due to diagnosis of the rare condition, neurofibromatosis 2 (NF2) when she was a teenager. The disease involves tumors in the brain, spinal cord and nerves. In Whitney's case, removal of the tumor caused her left eye to shut, and following chemotherapy and radiation she lost hearing in her right ear and later nearly $50 \%$ in her left ear. She was informed by physicians that she had a $50 \%$ chance of passing the condition to any child she might conceive, and that hormones associated with pregnancy could increase the chance of tumor growth. This news led to her decision to find a surrogate, but a friend's initial offer to do this never happened; this turn of events prompted her twin sister, Jill, to fill that important role. Jill is a former basketball star who played for Arizona State University. The pregnancy, which used donated eggs and the father's sperm, was successful after two attempts.

I am unaware of a similar situation in which a twin carried twins for her twin sister. However, I have described the incredible story of identical twins, Marcy and Tracy, which allowed Tracy to become a mother of two non-twin sisters on different occasions (Segal, 2005). Tracy had contracted Valley fever, which required drug treatments that would be harmful to a fetus, and if suspended would place Tracy in danger. After several unsuccessful IVF attempts, the twins decided (they claim without discussion) that Marcy would become impregnated with Tracy's husband's sperm. This allowed Tracy to become the mother of two daughters, Ella and Gianna. In this case, the unique advantage of having a genetically identical twin sister was that the children conceived by Marcy were fully related to Tracy - it was as if she had conceived them herself.

\section{Near Presidential Twin}

There has never been a US president who was a twin. However, identical twin General Winfield Scott Hancock had a near presidential win in 1880 , losing to Republican James A. Garfield by only about 10,000 votes (History.com, 2018). Following his defeat, he returned to his position at the Department of the Atlantic, then served as President of the National Rifle Association.

Hancock is known for his role as a Union general during the Civil War (1861-1865), especially the July 1863 Battle of Gettysburg where he resisted an assault by the Confederates known as Pickett's Charge. Following the war, he was variously involved with different divisions of the US Army. He passed away at the age of 61 years in 1886. His twin brother, Hilary, was an alcoholic, but outlived him by about 20 years; alcoholism occurred frequently in the twins' family (Blog Archive, 2013).

Currently, identical twin Julián Castro is running for the US presidency. He has served as mayor of San Antonio (2009-2014) and Secretary of Housing and Urban Development under President Barack Obama (2014-2017). His brother Joaquin is in the US Congress representing the state of Texas (2013-present). For more about the Castro twins, see Lambrecht (2019).

\section{References}

Austen, I. (2017). 2 survivors of Canada's first quintuplet clan reluctantly re-emerge. New York Times (North Bay Journal). Retrieved from https:// www.nytimes.com/2017/04/02/world/canada/ontario-dionne-quintuplets. html

Bell, J. (2019). Patriots twins relishing chance to be teammates for first time in a Super Bowl. USA Today. Retrieved from https:/www.usatoday.com/story/ sports/nfl/columnist/bell/2019/01/30/super-bowl-2019-devin-and-jasonmccourty-twins/2714006002/

Berton, P. (1977). The Dionne years: A thirties melodrama. New York: Norton. 
Blatz, W. E., Chant, N., Charles, M. W., Fletcher, M. I., Ford, N. H. C., Miilichamp, D. A. (1937). Collected studies on the Dionne quintuplets. Toronto, Canada: University of Toronto Press.

Blog Archive. (2013). The Hancock curse. Retrieved from http://thehancockcurse. blogspot.com/

Butler, J. (2018). The less you know the sounder you sleep. New York, NY: HarperCollins.

Campbell, D. M. (2005). Natural factors influencing multiple gestation: Perspectives from long-term observations in Scotland. In I. Bickstein \& L.G. Keith (Eds.), Multiple pregnancy: Epidemiology, gestation, and perinatal outcome (2nd ed., pp. 87-93). Boca Raton, FL: CRC Press.

Cassill, K. (1982). Twins: Nature's amazing mystery. New York, NY: Atheneum.

Cassill, K. (1984). The Twins Foundation: Twins take up the challenge. Acta Geneticae Medicae et Gemellologiae, 33, 523-525.

CBC Digital Archives. (1984). Canada's very own test tube baby. Retrieved from https://www.cbc.ca/archives/entry/canadas-very-own-test-tube-baby

CBCDocsPov. (2019, June 27). Inseparable: Ten years joined at the head. Retrieved from https://www.cbc.ca/cbcdocspov/episodes/inseparable

Colapinto, J. (2004). Gender gap: What were the real reasons behind David Reimer's suicide? Medical Examiner. Retrieved from https://slate.com/ technology/2004/06/why-did-david-reimer-commit-suicide.html

Comeau, E. (2013). First test-tube baby in U.S. reflects on the death of an IVF pioneer. Retrieved from http://www.boston.com/lifestyle/health/fitness/ getmoving-blog/2013/04/when_there_are.html

Craig, J. M., Segal, N. L., Umstad, M. P., Cutler, T. L., Keogh, L. A., Hopper, J. L., \& Harris, J. R. (2015). BJOG Debate. Zygosity testing should be recommended for all same sex twins. British Journal of Obstetrics and Gynecology, 122, 1641.

Crist, A. (2019). Super Bowl: New England Patriots Beat Los Angeles Rams 13-3. Hollywood Reporter. Retrieved from https://www.hollywoodreporter.com/ news/super-bowl-2019-winner-patriots-beat-rams-13-3-1182228

Dafoe, A. R. (1934). The Dionne quintuplets. Journal of the American Medical Association, 101, 673-677.

Diamond, M., \& Sigmundson, H. K. (1997). Sex reassignment at birth: Longterm reviews and clinical implications. Archives of Pediatric and Adolescent and Medicine, 151, 298-304.

Dionne Quints Heritage Board. (2019). The 5 ladies who put Northern Ontario on the map. Retrieved from https://dionnequintshome.com/

Dionne, A., Dionne, C., \& Dionne, Y. (2001). Advice from the Dionne. Time Magazine, Retrieved from http://content.time.com/time/magazine/article/ $0,9171,136960,00 \cdot \mathrm{html}$

Enrich, D. (2019, June 1). Spend some time with the Winkelvii. New York Times (Sunday Book Review), p. 58

Foster, S. R., \& Carson, W. (1923). A case of quintuple pregnancy. Lancet, 2, 120.

Fried, M. (2019). M.P. Rhinitis. Merck manual. Retrieved from https://www. merckmanuals.com/home/ear,-nose,-and-throat-disorders/nose-and-sinusdisorders/rhinitis

Garrett-Bakelman, F. E., Darshi, M., Green, S. J., Gur, R. C., Lin, L., Macias, B. R., . . Piening, B. D. (2019). The NASA Twins Study: A multidimensional analysis of a year-long human spaceflight. Science, 364, 144.

Graveland, B. (2019). Alberta couple welcomes third set of fraternal twins: 'We'll call it quits here'. Canadian News. Retrieved from https:// globalnews.ca/news/5271851/alberta-family-three-sets-fraternal-twins/

Hamblen, E. C., Baker, R. D., \& Derieux, G. D. (1937). Roentgenographic diagnosis and anatomic studies of a quintuple pregnancy. Journal of the American Medical Association, 109, 10-12.

Hightower, K. (2019). McCourty brothers Devin and Jason to be first twins to play on same Super Bowl Team. Super Bowl 53. The Associated Press.

History.com. (2018). Winfield Scott Hancock. Retrieved August 21 from https://www.history.com/topics/american-civil-war/winfield-scott-hancock

James, W. H. (1992). Coital frequency and twinning - A comment. Journal of Biosocial Science, 24, 135-136.

Juneau, J. (2019). Former women's basketball star is carrying twins - for her twin sister. People Magazine. Retrieved from https://people.com/parents/jillnoe-surrogate-for-twin-sister-whitney-bliesner-twin-babies/
Koenig, L. B., McGue, M., Krueger, R. F., \& Bouchard, T. J. Jr. (2005). Genetic and environmental influences on religiousness: Findings for current and retrospective religiousness ratings. Journal of Personality, 73, 471-488.

Koenis, M. M., Brouwer, R. M., Swagerman, S. C., van Soelen, I. L., Boomsma, D. I., \& Hulshoff Pol, H. E. (2018). Association between structural brain network efficiency and intelligence increases during adolescence. Human Brain Mapping, 39, 822-836.

Lambrecht, B. (2019). Twins Julián and Joaquin Castro step onto a national political stage - Together, as always. Houston Chronicle. Retrieved from https://www.houstonchronicle.com/news/politics/texas/article/Twins-Juli-nand-Joaquin-Castro-step-onto-13707267.php

Lång, E., \& Nystedt, P. (2018). Two by two, inch by inch: Height as an indicator of environmental conditions during childhood and its influence on earnings over the life cycle among twins. Economics \& Human Biology, 28, 53-66.

Latimer, J. (2017). The torture and sadness of Russia's most famous conjoined twins. Maclean's. Retrieved from https://www.macleans.ca/culture/books/ the-torture-and-sadness-of-russias-most-famous-conjoined-twins/

McCarthy, C. (2008). Sixth place in Beijing for Twin ConnectU founders. C/Net. Retrieved from https://www.cnet.com/news/sixth-place-in-beijingfor-twin-connectu-founders/

Mezrich, B. (2019). Bitcoin billionaires: A true story of genius, betrayal, and redemption. New York, NY: Flatiron Books.

Parga, J. A., \& Nansen, S. C. (2019). Heteropaternity of twins in ring-tailed lemurs (Lemur catta). American Journal of Physical Anthropology, 169, 270-278.

Pelletiere, N. (2019). Woman who carried twins for twin sister who couldn't get pregnant gives birth: 'Those kids are going to be so loved'. Good Morning America. Retrieved from https://www.goodmorningamerica.com/family/ story/woman-carried-twins-twin-sister-pregnant-birth-kids-63634395

Peraita-Adrados, R., Vicario, J. L., Tafti, M., García de León, M., \& Billiard, M. (2012). Monozygotic twins affected with Kleine-Levin syndrome. Sleep, 35, 595-596.

Prino, L. E., Pasta, T., Gastaldi, F. G. M., \& Longobardi, C. (2019). The graphical representation of the self-image in early development: Twins and singletons in comparison. Early Child Development and Care, 189, 1384-1395.

Seelye, K. Q. (2019). Gloria Schiff, 90. A fixture in New York's high society. New York Times, B12.

Segal, N. L. (1985). Holocaust twins: Their special bond. Psychology Today, 19, 52-58.

Segal, N. L. (1992). Twin research at Auschwitz-Birkenau: Implications for the use of Nazi data today. In A. Caplan (Ed.), When medicine went mad: Bioethics and the Holocaust (pp. 281-299). Totowa, NJ: Humana Press.

Segal, N. L. (2005). Indivisible by two: Lives of extraordinary twins. Cambridge, MA: Harvard University Press.

Segal, N. L. (2012). Born together-reared apart: The landmark Minnesota twin study. Cambridge, MA: Harvard University Press.

Segal, N. L. (2017). Twin mythconceptions: False beliefs, fables, and facts about twins. San Diego, CA: Elsevier.

Segal, N. L., Craig, J. M., \& Umstad, M. P. (2019). Challenge to the assumed rarity of heteropaternal superfecundation: Findings from a case report. Australian Journal of Forensic Sciences. Advance online publication. https://doi.org/10.1080/00450618.2019.1616821

Silva, M. J., Kilpatrick, N. M., Craig, J. M., Manton, D. J., Leong, P., Burgner, D. P., \& Scurrah, K. J. (2019). Genetic and early-life environmental influences on dental caries risk: A twin study. Pediatrics, 143, $167-174$.

Stubbe, J. H., Boomsma, D. I., \& de Geus, J. C. N. (2005). Sports participation during adolescence: A shift from environmental to genetic factors. Medicine and Science in Sports and Exercise, 37, 563-570.

Vieira, A. R., Modesto, A., \& Marazita, M. L. (2014). Caries: Review of human genetics research. Caries Research, 48, 491-506.

Wikipedia. (2019). Dionne quintuplets. Retrieved from https://en.wikipedia. org/wiki/Dionne_quintuplets\#Birth 